\title{
Shake-up urged for UK public research labs
}

London. Sweeping changes in the organization of Britain's government-run research institutions have been proposed by a team of civil servants that has for the past three months been carrying out an 'efficiency scrutiny' of the way in which such institutions are run.

In particular, the scrutiny team has proposed that separate institutes sharing a common research interest - for example food production or the marine environment - be brought together as agencies with a unified management structure.

Specific proposals cover most of the institutes run by the National Environment Research Council (NERC) and the newly formed Biotechnology and Biological Sciences Research Council(BBSRC). Although the agencies would still be 'owned' by the respective research councils, the new arrangements would sharpen the distinction between the 'sponsor/customer' role of the councils, and the 'supplier/contractor' role of the institutes.

In each case, a chief executive would be appointed over and above the current institute directors, with a specific remit to streamline organization and ensure "continuing economy, efficiency and effectiveness", including "any necessary refocusing of the missions of the laboratories".

No proposals are made for the Rutherford Appleton and Daresbury Laboratories run by the Engineering and Physical Sciences Research Council, which are the subject of a separate review. But members of the review team say there would be an "advantage" in applying a similar approach to institutes run by the Medical Research Council (MRC) "to reflect the same sponsor/ supplier division".

The preliminary conclusions of the review team, which were presented to government scientists and research council officials last Friday, do not propose the widescale privatization that many had feared.

Indeed, the group says that its scrutiny of 53 government laboratories has found "no clear-cut cases of suitability for early privatization" over and above those already identified in departmental reviews (such as the Transport Research Laboratory).

But, picking up on a suggestion first made last summer in a report by Sir Peter Levene, the government's efficiency adviser, and Bill Stewart, its chief scientific adviser, the group endorses the idea that the institutions be combined into a number of separate groupings managed relatively

\section{Jobs to go as the private sector moves in}

London. Michael Heseltine, the president of Britain's Board of Trade - and a potential challenger to the prime minister, John Major - announced last week that he had decided to take steps to privatize three of the United Kingdom's main government research laboratories now owned by the Department of Trade and Industry (DTI).

The National Physical Laboratory (NPL), the government's main body for developing and disseminating national standards and based at Teddington outside London, will remain under the DTI's ownership for the time being, but its management will be contracted out to the private sector.

The Laboratory of the Government Chemist, which carries out functions from drug detection for the customs service to assisting the police force with DNA analysis and shares the same site as the NPL, will be set up as an "independent non-profit distributing company" - although it could be sold outright "if a suitable buyer comes along".

The National Engineering Laboratory in Glasgow, which has already been slimmed down in preparation for eventual privatiza tion, will be put on the market in the summer of next year.

Heseltine's announcement had been widely anticipated. The government argues that privatization is needed to ensure that the laboratories become "more focused in their work, more sensitive to their custom- ers' requirements, and more cost-efficient". Indeed, despite concerns in both the scientific and industrial communities (see Nature 363, 196;1994), Heseltine is widely believed to have argued strongly for immediate privatization, and only backed off reluctantly when the desirability of such a step was challenged in a report prepared for the DTI by management consultants KPMG.

Nevertheless, the government's decision has generated a strong reaction from the opposition Labour party. Michael Meacher, the shadow minister for science, condemned the move as an "ideologically driven course" that will "undermine the industrial regeneration the country needs so desperately".

Cuts in DTI support are likely to lead to considerable job losses among scientists working at the three laboratories. The Institute of Professionals, Managers and Specialists, which represents the 700 scientists at the laboratories, describes the privatization decision as a "wanton destruction of a national resource", and says it runs "counter to the laboratories' mission to provide independent advice on technical issues".

Heseltine, however, remains adamant that the most important task facing each of the laboratories is to raise their ability to respond more flexibly to the needs of British industry, and that this can be best done from the private sector. independently of their sponsoring bodies.

The main research institutions supported by the NERC, for example, would be grouped as a single agency coordinating the activities of all government research institutions concerned with the non-marine environment, ranging from the British Geological Survey to the laboratories currently run by the Forestry Commission.

Institutions dealing with the marine environment would form a separate agency 'owned' by the Scottish Office (SO). This would include not only bodies currently run by the SO, such as the Fisheries Research Service, but also two NERC institutes, the Dunstaffnage Marine Laboratory and the Plymouth Marine Laboratory.

The BBSRC would 'own' government laboratories focusing on biotechnology and the biological sciences. Complementary to this would be a separate grouping of food and agriculture laboratories, primarily those now run by the Ministry of Agriculture Food and Fisheries, but also possibly including the Natural Resources Institute of the Overseas Development Agency. There would also be a grouping 'owned' by the Home Office of laboratories concentrating on forensic science.

In proposing these initial five agencies - and suggesting that a further two might be created for medical research and health services research - the review group has backed away from the alternative proposal made in the Levene/Stewart report creating a single Civil Defence Agency.

But it has suggested a number of government laboratories that might be taken over by neighbouring universities, including the Institute of Virology and Environmental Biology near Oxford and possibly the BBSRC's Institute for Animal Health at Babraham, close to Cambridge University.

Finally, the review group suggests that there should be "some scope for amalgamation" between the Public Health Laboratory Service and the laboratories run by the National Health Service.

In general, the scrutiny team's conclusions have been welcomed with a certain relief from those who had feared that it might lead to a full-scale sell-off of government laboratories. But there remains concern both about the implications of introducing a new level of bureaucracy, and about the changes that may be imposed on institutions under the new arrangements in order to prepare them for later privatization.

In particular, labour unions representing scientific staff at the institutes are nervous that a considerable number of jobs could be lost through the application of the scrutiny team's various proposals for achieving what it describes as "savings/flexible use of manpower" by linking together laboratories within a single agency.

David Dickson 